\title{
Pegmatites of the Larvik Plutonic Complex, Oslo Rift, Norway: field relations and characterisation
}

\author{
Øyvind Sunde' ${ }^{1}$ Henrik Friis ${ }^{1} \&$ Tom Andersen ${ }^{2}$ \\ ${ }^{1}$ Natural History Museum, University of Oslo, P.O. Box 1172, Blindern, 0318 Oslo, Norway. \\ ${ }^{2}$ Department of Geosciences, University of Oslo, P.O. Box 1047, Blindern, 0316 Oslo, Norway \\ E-mail corresponding author (Øyvind Sunde): oyvind.geologi@gmail.com
}

\begin{abstract}
The Larvik Plutonic Complex (LPC) contains pegmatites with a wide array of mineral assemblages and morphological features. The pegmatites have traditionally been described as nepheline syenite and syenite pegmatites which carry agpaitic or miaskitic mineral assemblages, respectively. However, several pegmatites fall outside this simple characterisation due to 'agpaitic-like' late magmatic mineral assemblages such as hiortdahlite and eudialyte group minerals. Morphological and mineralogical differences between pegmatites are not unique to, or related with, specific areas of the LPC. Compositional variation and deformation features of the host pluton are the main mechanisms for differing morphology and mineral assemblages between LPC pegmatites. Natrolite replacement of feldspathoid is the most common alteration feature in the nepheline syenite pegmatites. The extent of alteration is closely associated with crystallisation of saccharoidal albite and aegirine. Detailed description of a nepheline syenite pegmatite situated in the Sagåsen quarry provides new insights into the internal evolution and mineral distribution of a large representative pegmatite body. The most important mechanism driving hydrous alteration is the crystallisation of anhydrous primary minerals which leads to an immiscible hydrous fluid driving in situ alterations of primary mineral assemblages.
\end{abstract}

Keywords: Pegmatites, alkaline, Larvik Plutonic Complex

Electronic Supplement 1: Quarry and outcrop coordinates

Received 17. August 2018 / Accepted 28. February 2019 / Published online 20 June 2019

\section{Introduction}

Pegmatites associated with granitic systems have been extensively studied since the $19^{\text {th }}$ century (e.g., Jahns \& Burnham, 1969; Cerný, 1991; London, 2008). Pegmatites are defined as coarse-grained $(>2.5 \mathrm{~cm})$ igneous rocks derived from a melt source enriched in volatiles. In the vast literature on pegmatites, alkaline pegmatites, i.e., pegmatites related to peralkaline syenites and nepheline syenites, are less studied relative to those from granitic systems. Although the term pegmatite is coined towards coarse-grained rocks regardless of its host rock, there are some distinct differences between a granitic or alkaline pegmatite. Generally, alkaline pegmatites tend to occur within their source pluton and rarely intrude deep into country rocks, whereas granitic pegmatites are typically emplaced outside their granitic source. Alkaline pegmatites also tend to crystallise early liquidus assemblages containing high field strength elements (HFSE) such as $\mathrm{Na}-\mathrm{Zr}$ silicates and show extensive late magmatic alteration of primary feltspathoids (Brøgger, 1890; Vlasov et al., 1966; Sørensen, 1967). Generally, alkaline pegmatites exhibit increasing sodium content with late- to post-magmatic crystallisation of albite, aegirine and zeolites (Brøgger, 1890; Khomyakov, 1995; Larsen, 2010). Descriptive work on alkaline pegmatites and their mineral assemblages from the Lovozero, Khibina and Ilímaussaq intrusions have been carried out since the $19^{\text {th }}$ century (e.g., Ussing, 1912; Fersman, 1926; Sørensen, 1967). It was the pioneering work of

Sunde, Ø., Friis, H. \& Andersen, T. 2019: Pegmatites of the Larvik Plutonic Complex, Oslo Rift, Norway: field relations and characterisation. Norwegian Journal of Geology 99, 93-111. https://dx.doi.org/10.17850/njg99-1-05. 
Brøgger (1890) that provided the first step towards linking mineralogical diversity to pegmatite petrology in the Larvik Plutonic Complex (LPC). These rocks are low in alkalinity relative to those from the Kola Peninsula and southern Greenland with a molar $\mathrm{Na}+\mathrm{K} / \mathrm{Al} \approx 0.80$ (Ussing, 1912; Neumann, 1980; Sørensen, 1997). In an alkaline perspective, the LPC pegmatites represent rocks transitional between truly miaskitic and agpaitic assemblages (e.g., Andersen et al., 2010; Marks et al., 2011). During the early mineralogical investigations of the LPC pegmatites (e.g., Wöhler, 1826; Scheerer, 1843, 1852; Weibye, 1850; Brøgger, 1890) there were mainly two accessible outcrop areas; the Langesundsfjord archipelago and the shoreline south of the town Stavern (formerly Fredriksvärn). Brøgger noted two main suites of pegmatites; the Langesundsfjord- and Fredriksvärn suites which differed from each other based on different HFSE-minerals, which today are considered as agpaitic and miaskitic mineral assemblages, respectively. Primary mineral assemblages containing complex $\mathrm{Na}, \mathrm{Zr}$ silicates were observed in the former suite of pegmatites while relative simple mineral assemblages of zircon, titanite and zirconolite were characteristic for the latter (Brøgger, 1890). Since the late $19^{\text {th }}$ century, dimension stone mining of larvikite has continuously exposed new pegmatites within otherwise inaccessible areas of the LPC (Larsen, 2010) giving ideal three-dimensional cross-sections of several pegmatite outcrops. Pegmatites exposed by continuous mining are only temporarily available as they are considered a waste rock by the industry and quickly discarded. The aim of this paper is to document pegmatite field observations on selected pegmatite outcrops to identify and characterise pegmatite key features such as morphology, texture, paragenesis and alteration. Electronic Supplement 1 provides geographical coordinates of quarries and outcrops used in the study.

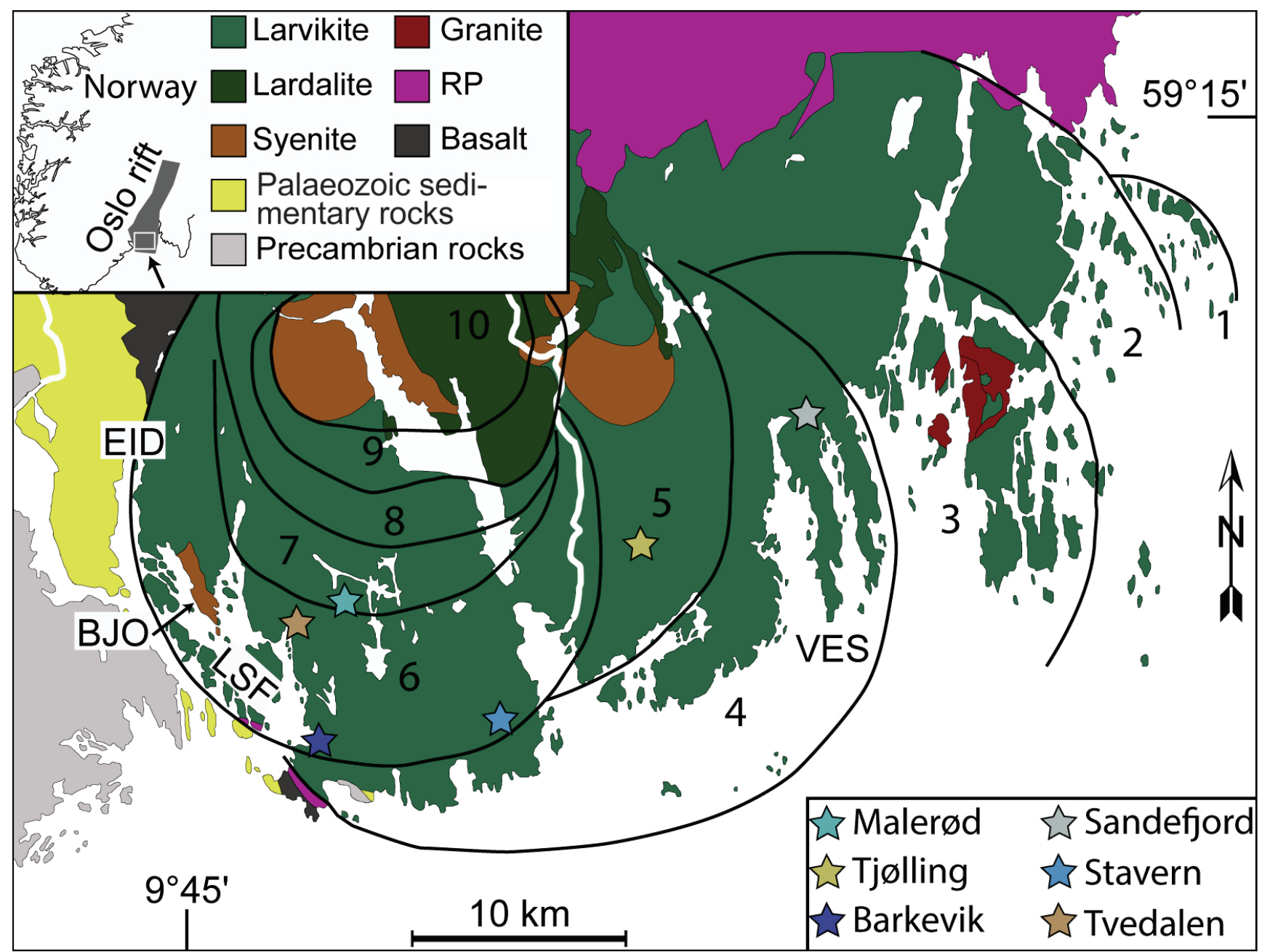

Figure 1. Simplified geological map of the Larvik Plutonic Complex modified from Petersen (1978) and Lutro \& Nordgulen (2008). Numbers 1-10 represent individual ring sections, inset map shows location of the Oslo Rift in Southeast Norway. Arrow indicates area of enlarged map and stars show the locations of the studied pegmatites. Geographical areas referred to in the text; EID - Eidanger, LSF - Langesundsfjord, VES - Vesterøya, BJO - Bjønnes peninsula. Geographical coordinates according to the WGS84 geodetic datum. 


\section{Geological background}

The Larvik Plutonic Complex comprises the oldest intrusive rocks belonging to the onshore part of the late Carboniferous to early Permian Oslo Rift (Neumann, 1980; Neumann et al., 2004). The LPC is a composite intrusive complex with 10 semi-concentric ring sections (RS) consisting of monzonites, nepheline syenite, nepheline monzonite (i.e., lardalite variety), and sodalite-bearing nepheline syenite (Fig. 1; Petersen, 1978; Neumann, 1980; Groome, 2017). Zircon uranium - lead ages indicate an emplacement period of 10 myr between RS 1 and RS 10 from $298 \pm 0.4$ to $289 \pm 0.5 \mathrm{Ma}$ (Rämo \& Andersen, 2011). The larvikites change in composition between quartz-bearing to nepheline-normative varieties in ring sections 1-8 whereas lardalite occurs in RS 9 and 10. Rythmic layering within the larvikite was described by Petersen (1978) as bands of elongated rhomb-shaped feldspars alternating with oxides and mafic minerals. These alternating layers range in thickness between 1 and $2 \mathrm{dm}$, and are observable on large exposures such as shore cliffs and sections within larvikite quarries. The ring intrusions consists of multiple batches of larvikite magma derived from a common parental melt situated at different crustal depths where in situ fractionation processes led to compositional change (Neumann, 1980). Nepheline syenite varieties are primarily situated within RS 6 as a confined pluton on the Bjønnes peninsula, but also as dykes and fissure fillings in the Langesundsfjord archipelago, Barkevik area, and Tveidalen quarry district (Fig. 1). Brøgger (1890) used the term "ditroit" and "foyait" as general terms to describe texturally different nepheline syenite varieties within the Langesundsfjord archipelago (i.e., not in the sense of Le Maitre et al., 2002). The nepheline syenite intruding the larvikite RS 6 is mostly fine grained with textural variations from strongly laminated fluid-flow to porphyritic textures (Groome, 2017). Large- and small-scale topographic lineaments of the LPC reveal several E-W and N-Strending fractures causing topographical depressions in the terrain. These fractures are confined between two, large, N-S-striking faults, which are observed in total magnetic field data (Fig. 2); however, the kinetics and displacement of these large faults are unknown.

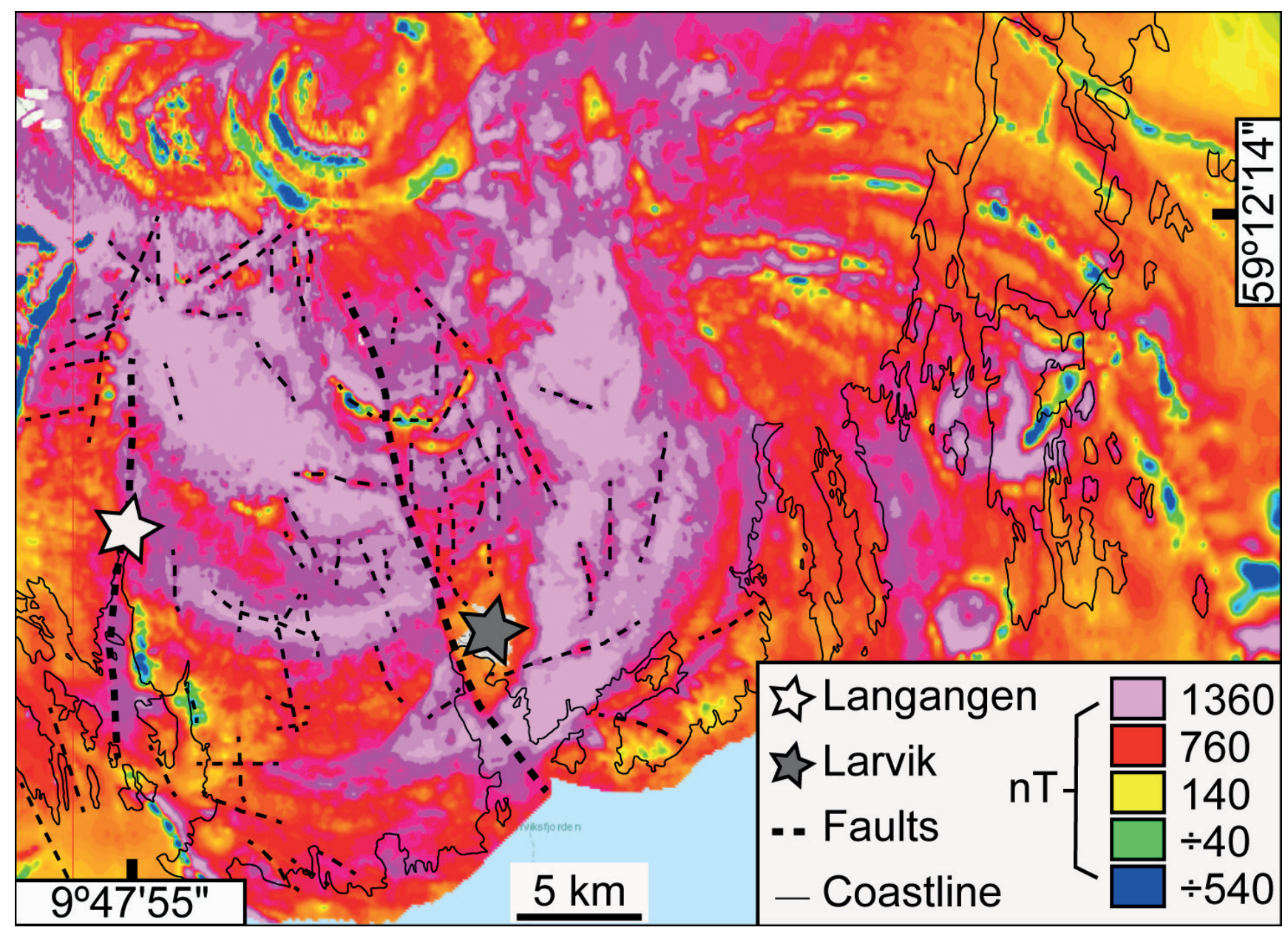

Figure 2. Geophysical map showing the total magnetic field of the LPC. Dashed lines indicate faulting or displacement with two of the largest faults situated at Langangen and Larvik. Relative differences in magnetic anomalies indicated between high and low nanotesla (nT). Modified from Heldal et al. (1999), Baranwal (2015), and GEOS Areas 1 and 2 (geophysical compilation map Mag_Oslo_Telemark_1981-2016; http://geo.ngu.no/GeosciencePortal/Results). 


\section{Data}

\section{Pegmatite emplacement and field relations}

The pegmatites of the LPC show different relationships with their host rocks (Fig. 3). The pegmatites may be emplaced within larvikite or fine-grained nepheline syenite. Nepheline syenite generally occurs in three different settings with pegmatites; 1) fine-grained nepheline syenite mixed into the pegmatite core (Fig. 3G, I), 2) nepheline syenite confined to the upper and lower pegmatite contact (Fig. 3F), or 3) nepheline syenite and pegmatite mixed in approximately equal proportions (Fig. 3A-D, H). Dykes consisting of only nepheline syenite are associated with pegmatite networks or rarely as isolated dykes (Fig. 3A-E). Nepheline syenite dykes are mostly related with pegmatites within RS 6 , but along the western LPC margin in the Langesundsfjord archipelago it is an intrusive phase in the larvikite (Brøgger, 1890; Groome, 2017). On the mainland, nepheline syenite is limited to dykes intruding larvikite in the Tvedalen and Barkevik areas (Fig. 1). These dykes are generally similar in thickness as the pegmatites (i.e., $30-50 \mathrm{~cm}$ thick). When pegmatites are hosted in larvikite without associated nepheline syenite, textural differences of the host-rock fabric are present between pegmatites and within individual pegmatites. Two types of larvikite contact textures dominate, namely; 1) shear deformation features (Fig. 4C) and 2) chilled margins (Fig. 4A). The shear deformation is characterised by orientation of preexisting mafic mineral assemblages of the host larvikite (e.g., amphibole) parallel to the pegmatite contact. The sheared larvikite may be deformed to different extents, from weakly deformed to strongly sheared textures. A chilled margin is here defined as comprising relatively fine-grained (e.g., $<2 \mathrm{~cm}$ ) primary minerals confined along the pegmatite contact with increasing crystal size inwards into the pegmatite. Both types of contact features may occur in one single pegmatite, e.g., the upper contact may be a chilled margin while the lower contact is strongly sheared. Sæbø (1966) briefly noted some of these features, but the mode of placement of nepheline syenite pegmatites within the host rock can be generalised as: 1) sheets (Fig. 4A, E), 2) kinked veins (Fig. 4B), and 3) stoped networks (Fig. 3E). Sheeted pegmatites occur as relatively isolated sheets when exposed in three dimensions and vary in thickness from a few centimetres and up to several metres thick. The Låven island and Sagåsen pegmatite 1 are among the largest pegmatites in the LPC with an apparent sheet-like geometry. Kinked veins are characterised by branching from one direction to another with a sudden stop in the larvikite. When these pegmatites change direction or stop within the host rock they typically follow pre-existing fractures with a subsequent directional change. Depending on the type of fracture (brittle or ductile) the pegmatite contact may appear with a sheared texture (Fig. 4C) or not. Stoped pegmatites occur as large pegmatite networks (e.g., larger than $10 \mathrm{~m}^{2}$ ) containing angular larvikite blocks suspended within the pegmatite body (Fig. 3A-D). These pegmatites may appear as several isolated individual pegmatites, but large three-dimensional exposures clearly show that these pegmatites are interconnected and the suspended blocks of larvikite can be several metres in size. These suspended larvikite blocks show a different orientation in their rhythmic layering relative to the surrounding larvikite (Fig. 3E). The stoped networks in particular display a complicated relationship between nepheline syenite and pegmatite where the networking veins contain either pegmatite, nepheline syenite, or a combination of the two different rocks. Suspended larvikite blocks are always angular and do not appear to have been remelted by the pegmatite. There is also no clear field evidence for any crossing relationship indicative of a relative intrusion history between the nepheline syenite and pegmatite.

Figure 3. Field images of stoped pegmatites and nepheline syenite occurring with pegmatite in Tvedalen. (A) West-facing wall-section in the Johs Nilsen quarry showing a network of pegmatite veins and angular larvikite breccia suspended within the pegmatite. The veins contain pegmatite, nepheline syenite, or mixed units of both pegmatite and nepheline syenite. (B) Sketch of Fig. 3A. Grey-larvikite, redmixed pegmatite and nepheline syenite, white - pegmatite. (C) South-facing wall-section of Fig. 3A, person for scale. (D) Sketch of Fig. 3C: Grey - larvikite, red - mixed pegmatite and nepheline syenite, white - pegmatite. (E) Several pegmatite veins connected in a stoped pegmatite at the Johs Nilsen quarry. The host larvikite shows a different orientation of the magmatic layering relative to suspended larvikite blocks. Black lines - orientation of magmatic layering, n.s - magmatic layering not observed; person for scale. $(F)$ Detailed field image of pegmatite, nepheline syenite, and larvikite contact (white box, Fig. 3C). Mixed pegmatite and nepheline syenite occur as patches with an unclear relationship between pegmatite and nepheline syenite. The mixed section has a visual composition of approximately 50\% pegmatite and 50\% nepheline syenite. (G) A nepheline syenite dyke parallel with a pegmatite, but branching into the pegmatite vein and filling the core of the pegmatite (FoW: $1 \times 1$ metre, Østskogen quarry, Tvedalen). (H) Detailed field image of mixed nepheline syenite and pegmatite in a stoped pegmatite. Note the subhedral to euhedral crystal habit of nepheline (brown crystals) and the defined contact between pegmatite and nepheline syenite. The surface is a cross-section semiperpendicular to the pegmatite vein (Utkleiv quarry, Tvedalen). (I) Pegmatite vein where nepheline syenite is concentrated in the core of the pegmatite (Johs Nilsen quarry, Tvedalen). Geographic coordinates (WGS84 geodetic datum) for Fig.

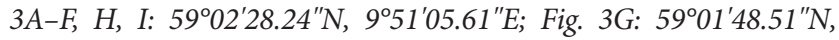
9०52'47.96"E. Abbreviations: L - larvikite, $M-$ mixed pegmatite and nepheline syenite, $N$ - nepheline syenite, $P$ - pegmatite. 


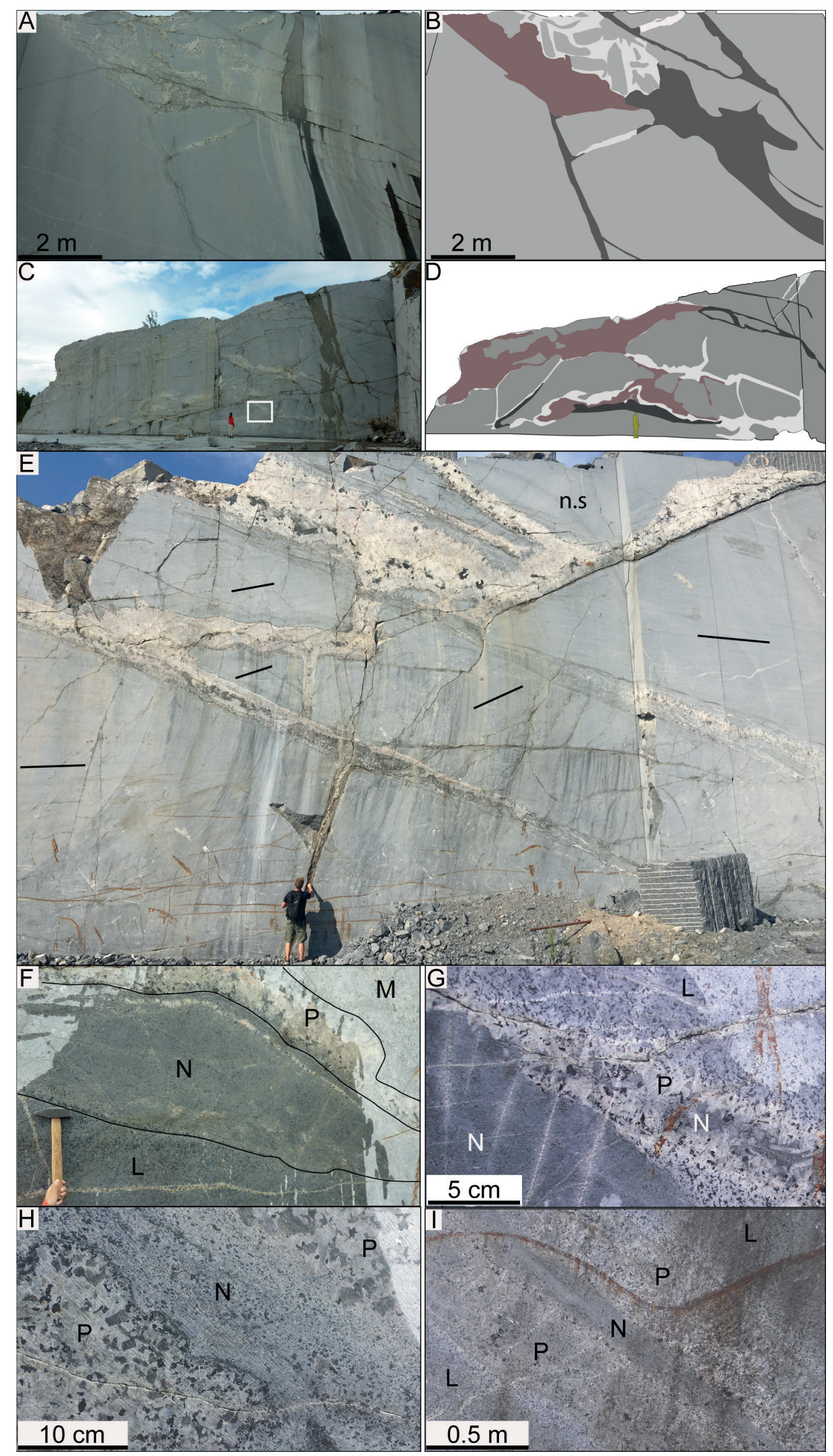




\section{Pegmatite mineral assemblages}

Early crystallised minerals are characterised by a subto euhedral crystal form, relative large crystal sizes (e.g., up to one metre across) and a specific, oriented direction of growth from the pegmatite contact and inwards (comb texture; Fig. 4). Microcline, nepheline, biotite, amphibole, pyroxene, magnetite and wöhlerite are typically among the primary magmatic mineral assemblages with a growth direction perpendicular to the wall-rock interface. In most cases, the primary mineral assemblage shows an increasing crystal size from the contact interface and towards the pegmatite core (Fig. $4 \mathrm{~A}, \mathrm{~B}$ ). However, some pegmatites have a homogeneous crystal size distribution in the cross-section. These types of pegmatites may consist of less diverse mineral
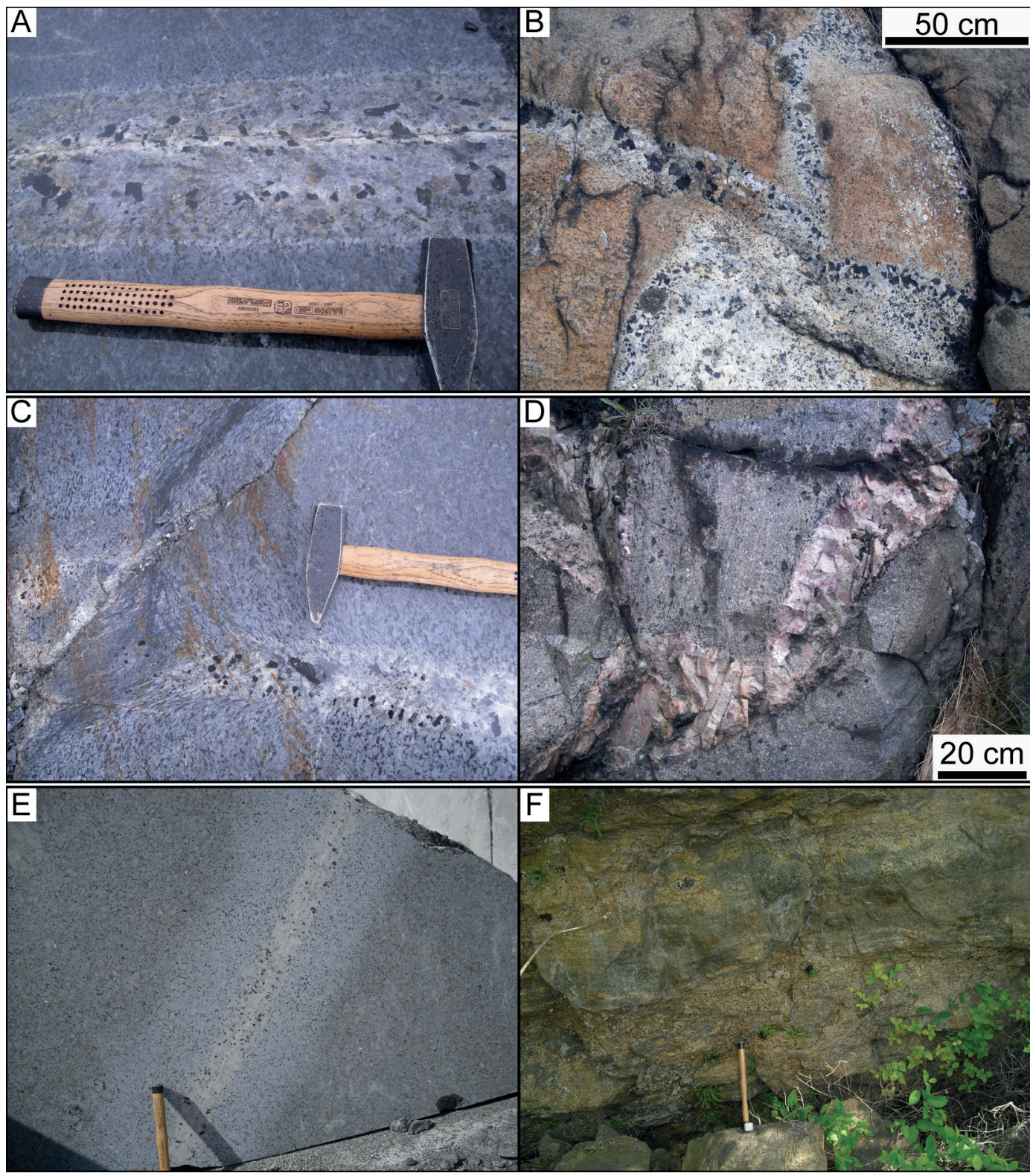

Figure 4. Field images of different styles of pegmatite and host-rock contacts. (A) Sharp interface between pegmatite and larvikite (Tuften quarry, Tvedalen). Microcline, nepheline, biotite and amphibole define the primary minerals growing inward from the larvikite contact with increasing crystal size from the contact interface (chilled). (B) A kinked pegmatite situated in larvikite (Barkevik). The field of view is $2 \times 2$ metres, brown discolouring of larvikite due to weathering. (C) Small pegmatite vein terminating towards a pre-existing shear zone in larvikite (Tuften quarry, Tvedalen). (D) A kinked pegmatite situated in nepheline syenite. The nepheline syenite is part of a several metre-thick dyke cutting through the larvikite in an $E-W$ direction at Barkevik (field of view $1 \times 1$ metre). The pegmatite vein is modally rich in feldspar and the crystals are large relative to the pegmatite thickness (i.e., >10\% of pegmatite thickness), and growing from one contact interface to the other. (E) A steeply dipping sheeted pegmatite in the Skallist quarry (Tjølling). Bleaching of the host larvikite is likely due to cerisite alteration of feldspar triggered by migrating fluids (e.g., Heldal et al., 1999). (F) Irregular upper contact of a subhorizontal pegmatite sheet oriented parallel to the magmatic layering of the host larvikite (Sandefjord). Smaller pegmatite druses and veins continue outwards from the pegmatite and into the host larvikite.

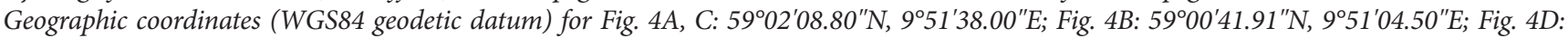

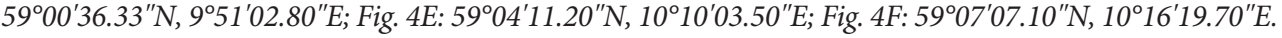


assemblages (e.g., microcline and nepheline) growing from the upper contact interface to the lower contact (Fig. 4D). Among the primary mineral assemblages, microcline and brown nepheline are the most modally abundant minerals in nepheline syenite pegmatite bodies of the LPC. The early mafic mineral assemblages consist of calcic-sodic amphiboles (i.e., ferro-edenite formerly known as barkevikite), magnetite and diopsidic clinopyroxene (Piilonen et al., 2013). The pyroxene composition evolves from diopside towards aegirine where pure aegirine crystallises in the late magmatic assemblages related to albite. Magnetite has exolution lamellae of ulvöspinel and is commonly altered around the rim to annite (Larsen, 1998). The late magmatic mineralisation is characterised by fine-grained albite (i.e., saccharoidal) forming interstitially to primary magmatic minerals (e.g., microcline, sodalite, nepheline; Fig. 5). In many cases, primary minerals are altered when either enclosed or partly in contact with saccharoidal albite. Most typical is the zeolite replacement of feldspathoids (mainly sodalite and nepheline). In most cases it is impossible to identify what feldspathoid was altered, however relict grain boundaries with preserved crystal habits are sometimes visible suggesting either nepheline (e.g., pseudo-hexagonal) or sodalite as the precursor (Fig. 6). When primary sodalite, which is typically green, is replaced by the cancrinite a secondary blue sodalite is typically observed (Fig. 5A, D). Minerals belonging to the eudialyte group minerals (EGMs) are mainly found as primary subhedral crystals in pegmatites within the Langesund archipelago, or as a late magmatic phase within saccharoidal albite in other pegmatites (Fig. 7C, D). Late magmatic EGMs are completely anhedral, fine grained, and associated with saccharoidal albite, altered sodalite and wöhlerite. Primary amphiboles are in many cases mantled by a mix of biotite and aegirine as a form of replacement alteration (e.g., Piilonen et al., 2013). This type of alteration appears fibrous and may vary in thickness from a thin rim to a complete replacement of the amphibole. Wöhlerite crystals in direct contact with saccharoidal albite are always altered into secondary zircon, pyrochlore and carbonate (Fig. 5B). Wöhlerite may also be altered around the rim with the association of fluorite and hiortdahlite (Andersen et al., 2013).

\section{Case study of the Sagåsen quarry}

The now abandoned Sagåsen quarry was chosen as a case study because it contains pegmatites with different orientation, size and host-rock relationship. Fig. 8 shows the location of studied pegmatites within the Sagåsen quarry labelled as pegmatites 1 to 5 . These pegmatites are sheets with different orientations relative to each other, and range in thickness from a few centimetres and up to $>2 \mathrm{~m}$ (Fig. 8). Nepheline syenite is found in association

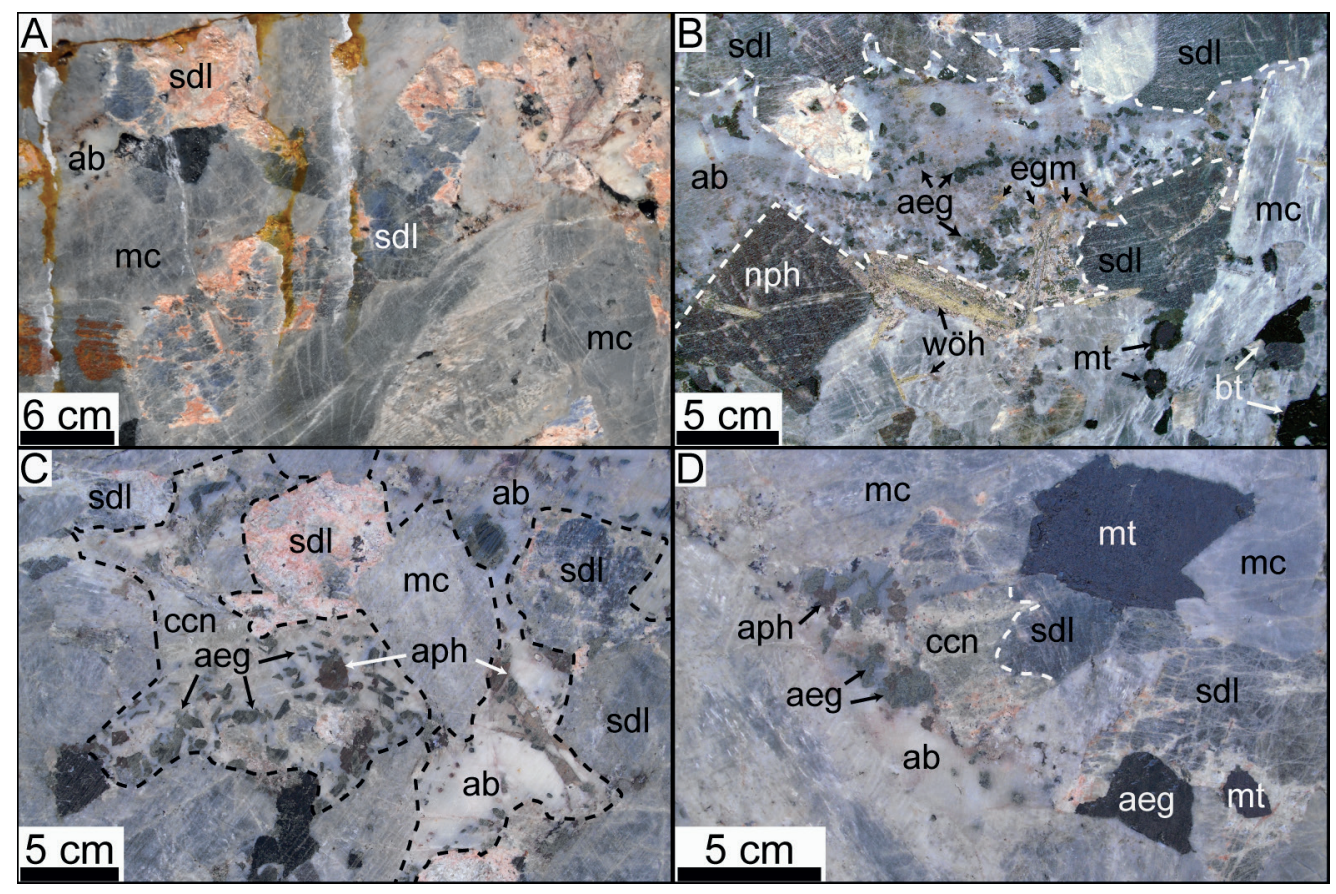

Figure 5. Field images of in situ natrolite replacement of primary sodalite. (A) Secondary blue sodalite (sdl) associated with natrolite (ntr) replacement in primary sodalite. (B) Alteration of sodalite and wöhlerite (wöh) in contact with albite (ab). The eudialyte group mineral (egm) is situated within albite. (C) Typical sodalite relationship with albite and progressive natrolite and cancrinite alteration. Dashed lines show interstitial saccharoidal albite hosting aegirine, cancrinite (ccn) and astrophyllite (aph). (D) Progressive in situ cancrinite alteration in sodalite (dashed line shows the protruding cancrinite). All images are from pegmatite 1 in the Sagåsen quarry. Mineral abbreviations: ab - albite, aeg - aegirine, aph - astrophyllite, bt - biotite, ccn - cancrinite, egm - eudialyte group mineral, mc - microcline, $m t$ - magnetite, nph - nepheline, sdl - sodalite, wöh - wöhlerite. 




Figure 6. Field images showing common alteration types of major mineral assemblages in the LPC pegmatites. (A) Complete natrolite (ntr) replacement of feldspathoid. The alteration occurs with albite (ab), aegirine and biotite (bt) (Pegmatite 2, Sagåsen quarry). (B) Alteration of amphibole where the crystal rim is replaced by aegirine \pm biotite (Sagåsen quarry, pegmatite 1). (C) Natrolite and biotite replacement in feldspathoid and magnetite, respectively (AS Granit quarry). (D) Partially altered nepheline along the contact towards larvikite. Relict nepheline crystal-boundary towards albite can be seen in the replacement zone. Aegirine, albite and astrophyllite fill interstices of microcline (Sagåsen quarry, pegmatite 2). Abbreviations: ab - albite, aeg - aegirine, amp - amphibole, aph - astrophyllite, bt - biotite, lvk - larvikite, $m c$ - microcline, $m t$ magnetite, nph-nepheline, ntr-natrolite.

with two of the pegmatites (pegmatite 1 and 5) where it forms a $10-30 \mathrm{~cm}$-thick band along the upper and lower contacts. Detailed study of the internal structure and mineral assemblages were conducted for pegmatite 1 and 2 because these exposures are sufficiently large to study variations along a profile. Pegmatite 1 is the largest body situated at the bottom of the quarry where the pegmatite reaches an exposed thickness of $2 \mathrm{~m}$ oriented N132E dipping at 18 degrees (Fig. 8A). The exposure is cut parallel to the strike trend where the mineral assemblages can be followed from one end and approximately 56 $\mathrm{m}$ until the pegmatite disappears into an unquarried part. Based on characteristic mineral assemblages the pegmatite is subdivided into three main segments.

\section{Segment 1}

Figs. 9 \& 10 show the characteristic features of segment 1 which includes three veins, varying between 10 and $20 \mathrm{~cm}$ in thickness, which merge into one continuous body. The host rock immediately surrounding and filling the space between these veins is a coarse-grained rock containing a mixture of pegmatitic material, nepheline syenite and larvikite. The most abundant minerals of this mixed rock are microcline, nepheline and biotite. The three veins merging into one larger body are different in respect to the host-rock contact. The upper and lower veins have a $10 \mathrm{~cm}$-thick rim of nepheline syenite, which defines a sharp contact towards the host larvikite (Fig. 10). Microcline, nepheline, amphibole, aegirine and cancrinite are the most abundant minerals in these veins where cancrinite occurs as an interstitial phase (i.e., not a replacement mineral). The microcline in the middle sheet does not appear to be growing with a comb texture perpendicular to the contact, but continues into the mixed rock where it forms bands or patches of microcline. Similarly, biotite and nepheline form bands and patches of mineral aggregates in the mixed rock. Fig. 9A shows the area where the three veins merge into one continuous pegmatite body. Here, the uppermost and lowermost pegmatite contacts are enveloped by nepheline syenite and the main pegmatite body is defined by the directional crystal growth inwards. Within this segment of the pegmatite there are large differences in crystal size between margin and core. From the upper and lower contacts the crystal size is decreasing and three generalised domains are recognised (Fig. 9B): 1) Large crystals $(\sim 50 \mathrm{~cm})$ growing from the pegmatite contact and inwards (comb texture). 2) Medium-sized crystals (between 2 and $10 \mathrm{~cm}$ ) which both mantle the large crystals (1) and form interstitially to these; however, the crystal growth may also be orientated parallel to the pegmatite body. That is, the strongly directional growth of the comb texture is restricted to the large crystals at the contact interface. 3) The mid to lower half of the pegmatite consists of very fine-grained crystals up to 1 


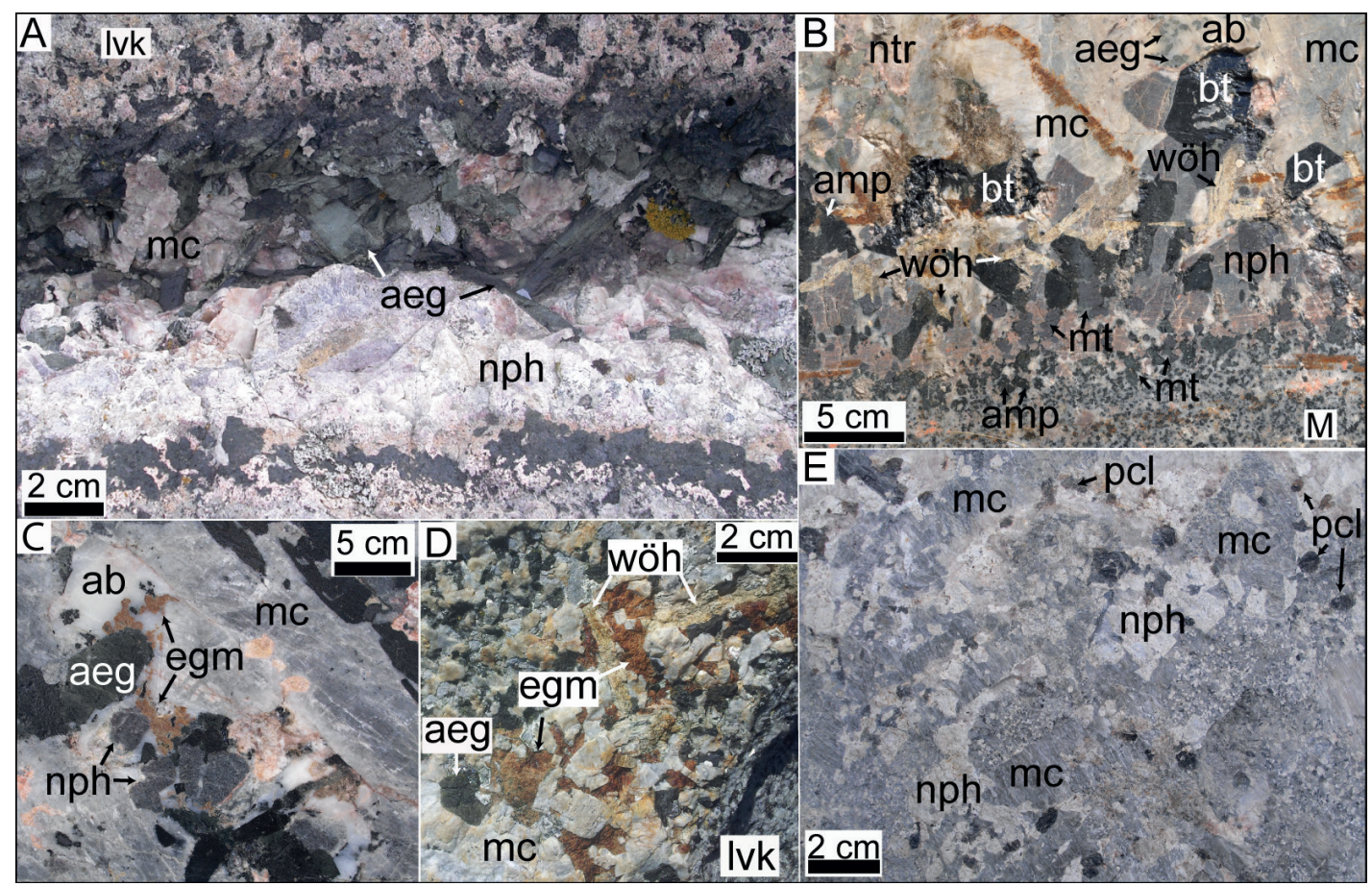

Figure 7. Outcrop images showing mineral assemblages of different pegmatites in the LPC. (A) Pegmatite vein at the Arøyskjor in the Langesundsfjord archipelago. Aegirine (aeg) occurs as a primary pyroxene growing perpendicular from the pegmatite interface. Nepheline (nph) is relatively altered, but without any adjacent albite (ab). (B) Primary mineral assemblage along the bottom contact of pegmatite 1 in the Sagåsen quarry. Wöhlerite (wöh) crystallised as euhedral prismatic crystals both poikilitic and interstitial to magnetite (mt), microcline (mc), nepheline (nph) and amphibole (amp). (C) Late mineral assemblage consisting of anhedral eudialyte group mineral (egm) occurring within confined albite (ab) pockets of pegmatite 1 in the Sagåsen quarry. (D) Anhedral eudialyte (egm) masses interstitial with microcline and wöhlerite (wöh). Wöhlerite is not altered and is in a stable configuration with eudialyte (Barkevika). (E) Field image of typical mineral assemblage of sheeted pegmatites in the Vardeåsen quarry. Nepheline ( $\mathrm{nph}$ ), microcline $(\mathrm{mc})$ and pyrochlore (pcl) form both coarse-grained and fine-grained crystals. Geographic

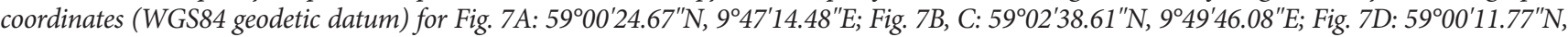
$9^{\circ} 51^{\prime} 02.74 " \mathrm{E}$; Fig. 7E: 59 $04^{\prime} 57.14^{\prime \prime} \mathrm{N}$, 9०56'27.28"E. Abbreviations: ab - albite, aeg - aegirine, amp - amphibole, bt - biotite, egm - eudialyte group mineral, lvk - larvikite, $m c$ - microcline, $m t$ - magnetite, $n p h$ - nepheline, ntr - natrolite, pcl-pyrochlore, wöh - wöhlerite.

$\mathrm{mm}$ long and connects the three merging veins. Along the transition between the medium-sized crystals (2) and the lower fine-grained zone (3) is a narrow zone consisting of aegirine, nepheline and microcline, which are oriented subparallel to the pegmatite body. The coarse-grained zone (1) consists of the primary mineral assemblage nepheline, microcline, biotite and amphibole. These minerals, as well as wöhlerite, pyroxene and magnetite, are the most modally abundant minerals in this zone. The majority of the feldspathoids are either partly or completely replaced by natrolite giving the pegmatite in this segment a reddish colour. The same alteration is visible in the thin nepheline syenite rim along the upper and lower contacts. The fine-grained zone (3) consists of saccharoidal albite mixed with analcime, giving this zone a patchy colour of white, grey, green and light-red depending on the content of fine-grained aegirine, natrolite and biotite. Biotite always occurs with a skeletal form as rounded patches dispersed within the saccharoidal albite, but these biotite patches may also locally be mantled with millimetre-size aggregates of aegirine. Secondary zircon, typically $1-2 \mathrm{~mm}$ large, forms patched aggregates within the saccharoidal albite.

\section{Segment 2}

This segment is a transition from segment 1 where the saccharoidal albite unit is terminated (Fig. 11). Saccharoidal albite in segment 2 is confined to interstitial spaces between large crystals of the primary mineral assemblage (e.g., microcline and nepheline). The crystal sizes increase from $2-5 \mathrm{~cm}$ at the contacts to metre-size crystals within the core where microcline and biotite are the largest crystals. Along the bottom contact wöhlerite is abundant where it occurs poikilitic within biotite aggregates and as crystals up to $10 \mathrm{~cm}$ in size (Fig. 7B). The upper contact consists mainly of microcline, nepheline and altered feltspathoids (i.e., natrolite replacement). Alteration of feltspathoids is strongest towards the transition from segment 1, but decreases towards segment 3. Parallel to the upper contact there is an approximately $20-30 \mathrm{~cm}$-thick zone of nepheline syenite (Fig. 11B). The contact between the pegmatite and the nepheline syenite is sharply defined by the crystal growth from the interface and inwards into the pegmatite, but the contact between the nepheline syenite and larvikite is also defined by such inward growth of early formed crystals. Within the nepheline 




Figure 8. Overview images of pegmatites situated in the Sagåsen quarry. (A) Northeast view of the Sagåsen quarry. Numbers 1-5 refer to different pegmatites mentioned in the text. Pegmatite 1 is situated in the lowermost level of the quarry and the target for the detailed study. Pegmatite 2 is exposed in the floor section, pegmatite 3 is situated in the SE-facing wall (Fig. 8E). Pegmatite 4 is a small remnant of the Saga I pegmatite (e.g., Larsen, 2010). Pegmatite 5 is situated in the upper level of the quarry. Grey circle indicates point of view (PoW) for Fig. 8B-D. Pegmatites 1 and 5 are associated with nepheline syenite, while pegmatites 2-4 are only associated with larvikite. (B) Three pegmatite sheets of varying thickness running parallel in the SE corner of the quarry. (C) A 5-10 cm-thick pegmatite on the SE-facing wall (pegmatite 3 in Fig. 8A). (D) Northeast-facing wall with a pegmatite terminating against a pre-existing fracture in the larvikite (dashed line). Geographic coordinates

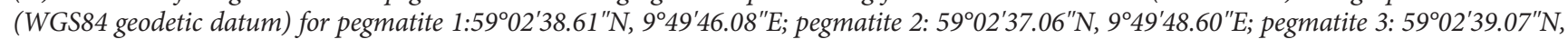



syenite minor apophyses, $2-5 \mathrm{~cm}$ thick, run parallel to the pegmatite body. The difference between these upper contacts, pegmatite-nepheline syenite and nepheline syenite-larvikite, are the minerals which crystallise along the contact interface. The contacts between the larvikite and nepheline syenite consist mainly of microcline and nepheline, while the contact between the pegmatite and nepheline syenite consists of microcline, nepheline, biotite, amphibole and alteration of feldspathoids. There is a weak bleaching of the larvikite, approximately $10 \mathrm{~cm}$ from the contact to the nepheline syenite (Fig. 11B). Within the nepheline syenite zone it is mainly the pegmatite apophyses that carry mafic minerals. The most abundant mafic minerals in segment 2 are biotite and magnetite. Magnetite is mainly concentrated along the bottom contact and typically has biotite replacement along the rims.

\section{Segment 3}

Segment 3 is characterised by a homogeneous distribution of metre-sized microcline and sodalite crystals. Saccharoidal albite is confined to isolated pockets interstitial to primary mineral assemblages in a similar style as segment 2 . Sodalite is a major mineral phase in segment 3 and defines a sodalite zone with a sharp transition between segments 2 and 3 (Fig. 12). 


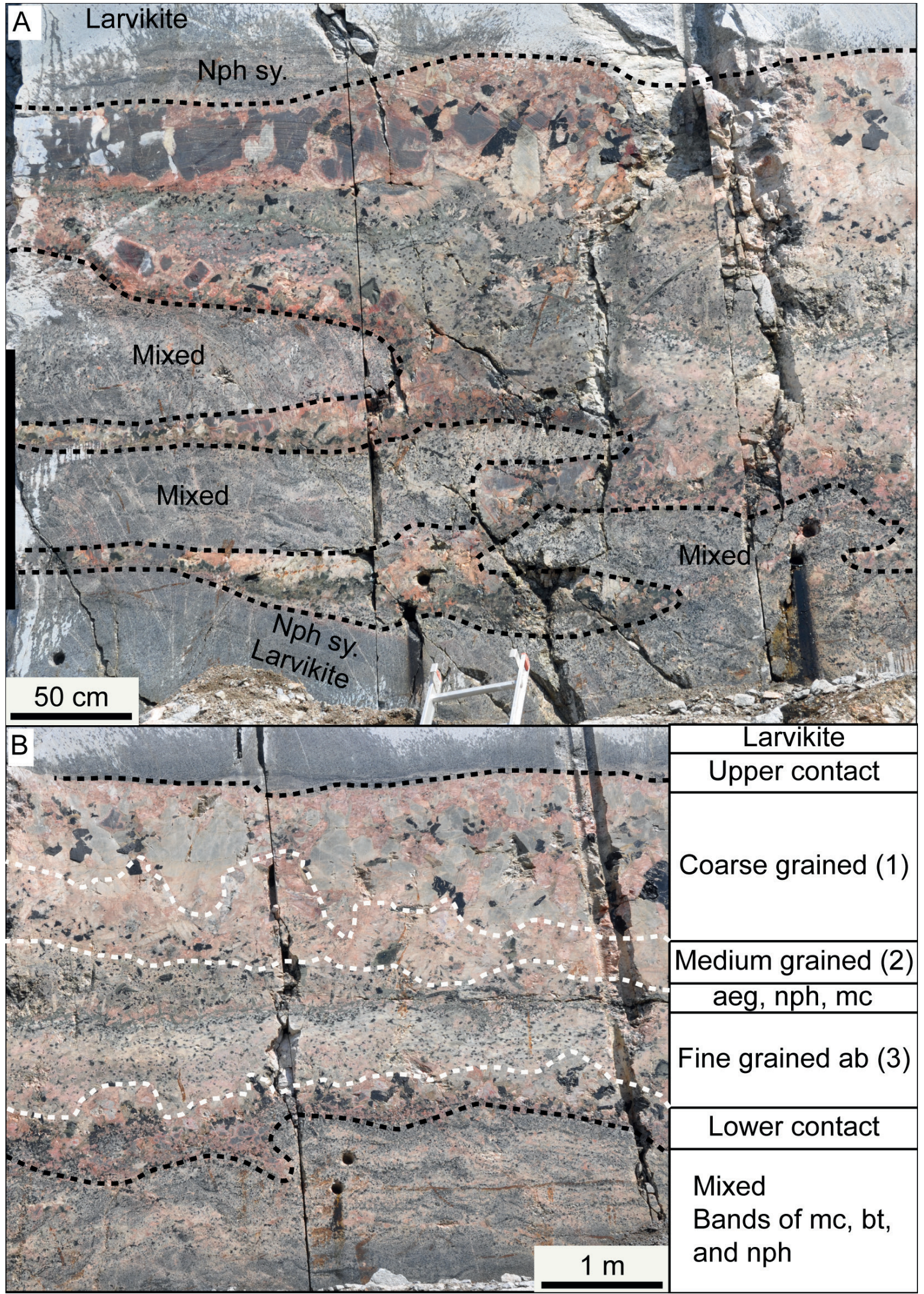

Figure 9. Field images showing features of segment 1. (A) Three pegmatite veins merge into one large pegmatite body. Dashed lines outline the pegmatite body with zones of mixed pegmatite and nepheline syenite. Black line indicates the view direction of Fig. 10. (B) Field image of segment 1 showing the distribution of relative crystal sizes (dashed lines). Albite (3) occurs in the lower half of the pegmatite with aegirine, nepheline and microcline forming a confined zone between albite (3) and the medium grained zone (2). Abbreviations: ab - albite, aeg - aegirine, bt - biotite, mc - microcline, nph - nepheline, neph sy. - nepheline syenite. 




Figure 10. Detailed field image of the lower and middle pegmatite vein in segment 1. Nepheline syenite is seen surrounding the lower vein, whereas the middle vein has an unclear relationship with the mixed rock (area marked by [?]). The mixed rock comrises heterogeneous bands consisting of microcline, biotite, or nepheline. Zones of microcline merge into the defined portion of the middle vein with a defined contact towards the host rock $($ scale $=10 \mathrm{~cm})$. View is perpendicular to Figure 9. The inset figure shows the relationship between pegmatite, nepheline syenite and larvikite (dashed lines), and mineral assemblages of the pegmatite veins. Abbreviations: aeg - aegirine, amp - amphibole, bt - biotite, ccr - cancrinite, $m c$ - microcline, $n p h$ - nepheline, nph sy. - nepheline syenite.

Sodalite grows as both prismatic and blocky crystals mostly oriented perpendicular to the upper pegmatite contact. Some sodalite crystals are up to 1 metre long, but smaller subhedral blocky crystals are concentrated within the core of this segment. These sodalite crystals are primary crystals with a green colour, whereas nepheline is distinctly brown. However, fine-grained, millimetre-size sodalite also occurs within nepheline syenite enclosing the pegmatite, but is also confined within segment 3 (Fig. 12). Many of the sodalite crystals show progressive alteration along the crystal boundaries with replacement of natrolite and cancrinite (e.g., Fig. 5A). Cancrinite replacement in primary sodalite is related to a secondary blue sodalite variety (Fig. 5D). Eudialyte group minerals only occur within segment 3 and are confined to interstitial saccharoidal albite. Anhedral masses of EGMs are brown to orange ferrokentbrooksite and yellow zirsillite-(Ce) (Larsen et al., 2005). Aegirine, secondary zircon and biotite also occur with EGMs, and during the period of active mining of the pegmatite large quantities of astrophyllite and leucophanite were found associated with sodalite (Larsen et al., 2005; Larsen, 2010). Thus, segment 3 defines the most diverse mineral assemblages within the pegmatite.

\section{Other pegmatites of Sagåsen}

Pegmatite 2 (Fig. 8A) is exposed on the quarry floor by an approximately $8 \mathrm{~m}$ long and $50 \mathrm{~cm}$-thick sheet oriented N260W dipping at 80 degrees. The pegmatite is not associated with nepheline syenite such as pegmatite 1 (e.g., nepheline syenite along the upper and lower contacts). However, this pegmatite also contains latemagmatic crystallisation of saccharoidal albite (Fig. 13) filling interstitials between microcline, nepheline and biotite. Aegirine crystallised contemporaneously with albite and forms 2-5 cm-long euhedral to subhedral crystals. Feldspathoids in contact with saccharoidal albite are completely altered, while nepheline along the upper and lower contacts is partly replaced by natrolite (Fig. 13C, D). Astrophyllite and cancrinite only occur as masses in association with saccharoidal albite, but eudialyte has not been observed in the exposed section of this pegmatite. The bottom contact consists of 2-4 $\mathrm{cm}$-long wöhlerite crystals, magnetite, microcline and minor nepheline. The upper contact relative to the bottom contact is rich in nepheline, but the nepheline content is not uniformly distributed along the upper contact. The core and lower half of the pegmatite consist mainly of saccharoidal albite and aegirine along the exposed section where it fills the interstitials between microcline crystals. 


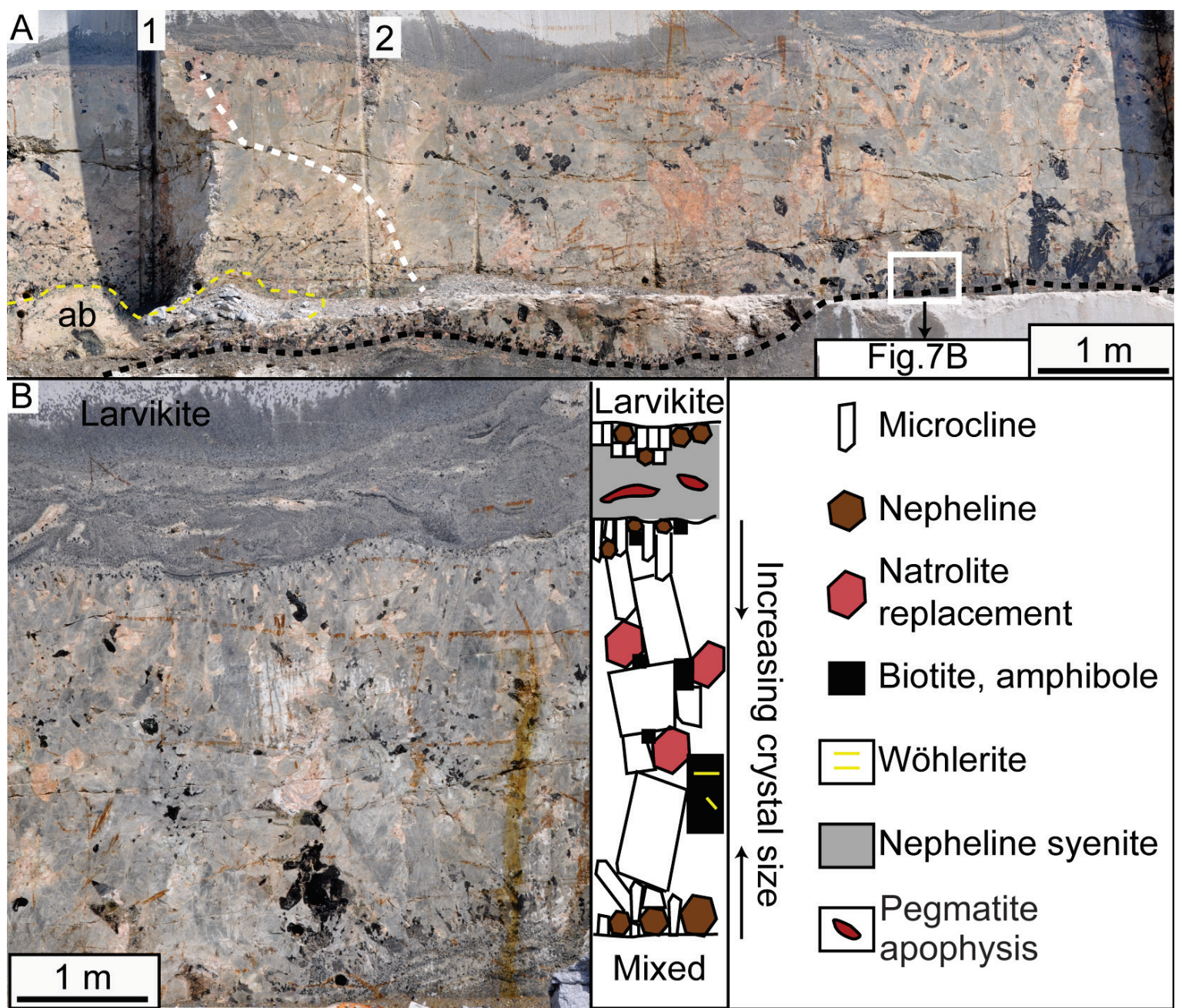

Figure 11. Field images showing features of segment 2. (A) The transition from segment 1 to segment 2 (white dashed line). The albite zone in segment 1 ( $a b$; yellow dashed line) terminates and the crystal size increases from the upper contact and inwards. White box indicates the area of Fig. 7B. (B) Field image of the upper contact showing a zone consisting of nepheline syenite containing small pegmatite apophysis(?). The contact between nepheline syenite and larvikite shows a comb texture of mainly microcline and nepheline syenite. The contact interface between pegmatite and nepheline syenite shows an oriented directional growth of microcline with interstitial nepheline and altered feldspathoid. Biotite is the most abundant mafic mineral in segment 2.

\section{Discussion}

Timing of pegmatite and nepheline syenite emplacement

Pegmatites with a relationship to nepheline syenite are mainly confined within RS 6 (Fig. 1). Dahlgren et al. (1998) reported zircon and baddeleyite $\mathrm{U}-\mathrm{Pb}$ ages from RS 6 larvikite and pegmatite with $293.2 \pm 1.3$ and $294.3 \pm 1.2 \mathrm{Ma}$, respectively. Larsen et al. (2017) reported molybdenite Re-Os ages of $289 \pm 1$ and 287 $\pm 1 \mathrm{Ma}$ from pegmatite 1 and 4 in the Sagåsen quarry, respectively. Molybdenite Re-Os ages were interpreted as representative for the late-magmatic hydrous alteration. Considering the uncertainty of these reported ages, and the relatively short magmatic history of the LPC (e.g., 10 myr; Rämo \& Andersen, 2011), age constraints between pegmatites and ring sections are not significantly separated in time. Field observations suggest that the pegmatites and nepheline syenite were intruded within the same period of time in the host larvikite. As already noted by Brøgger (1890), the larvikite was still hot when the pegmatites and nepheline syenite were emplaced. The resolution of the available chronological data may not pinpoint when the pegmatites were emplaced. However, two key field observations support this qualitative statement. Firstly, unaltered larvikite blocks are found suspended within stoped pegmatites, which indicates a close timing with nepheline syenite. Secondly, pegmatiteforming melts must have utilised fractures already present in the host larvikite, where both brittle fractures and ductile shear-zones already existed. Nepheline syenite in dykes associated with pegmatites is related to an evolved derivate from RS 6 larvikite (Groome, 2017). Chemical variation between pegmatites situated in larvikite with or without nepheline syenite show that these rocks are related to a common source (Sunde et al., 2018). Furthermore, the major and trace element signature of wöhlerites from the different pegmatites 


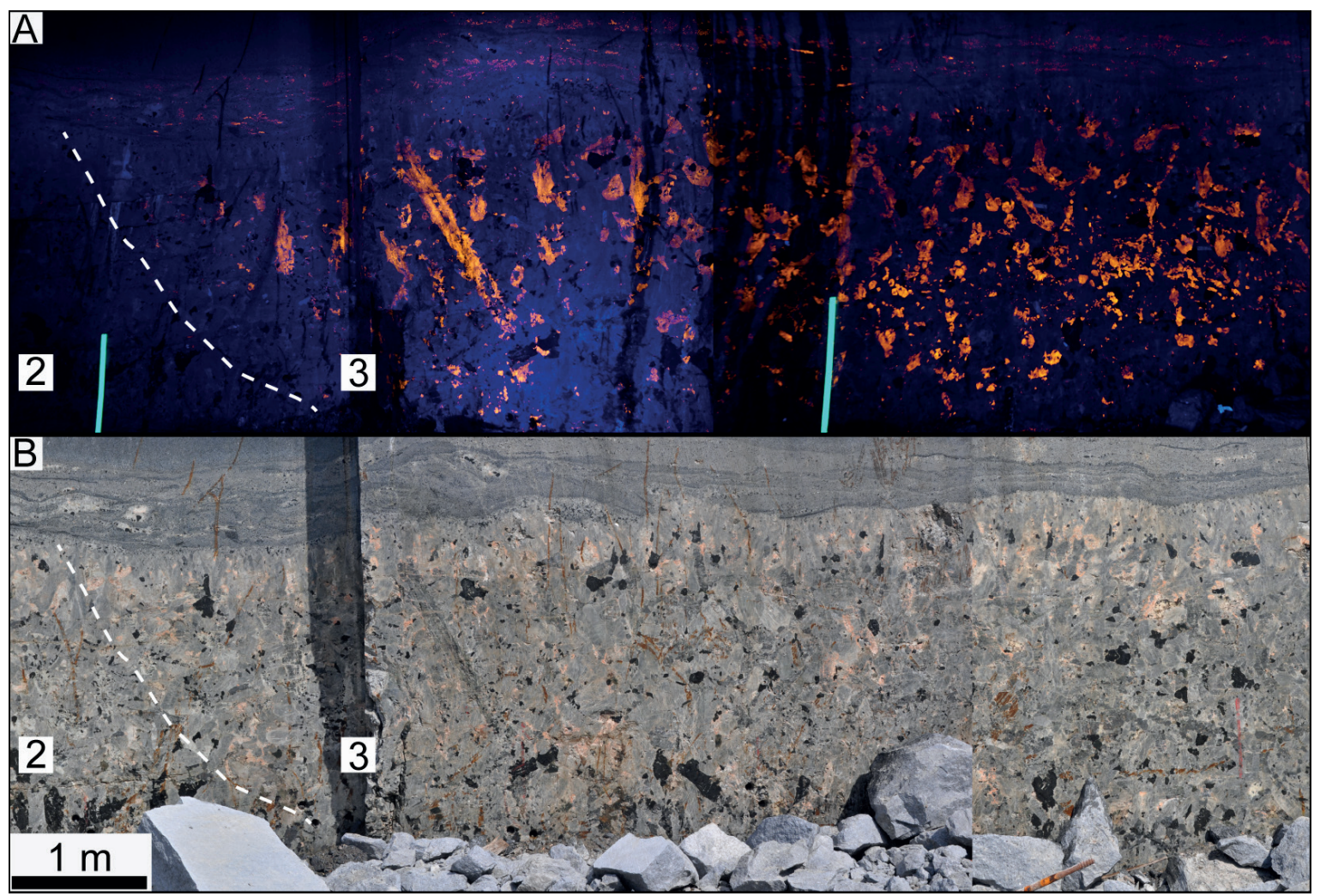

Figure 12. Field images showing the transition between segments 2 and 3. (A) Photograph of fluorescent sodalite with a characteristic yellow and orange fluorescence colour when exposed to short wave $(365 \mathrm{~nm})$ ultra-violet (UV) light. Segment 3 is modally rich in unaltered sodalite as opposed to segment 2. Note the fine-grained sodalite distributed within nepheline syenite along the upper contact. (B) Photograph showing the same cross-section as Fig. 12A. Dashed line shows the transition between segments 2 and 3 as numbered.

within the Sagåsen quarry are identical, supporting a common source despite their difference in size, orientation, contact relations and mineralogy (Sunde et al., 2018). Therefore, our current knowledge suggests that both nepheline syenite and pegmatites in RS 6 were emplaced within a short, but similar time-frame.

\section{Pegmatite structural control}

Regional large-scale lineaments are visible on geophysical data (Fig. 2) as well as topographical expressions in the terrain. Particularly in the Tvedalen area N-S and E-Wtrending lineaments define the topography as troughs and ridges. These lineaments are most pronounced between the two N-S-striking faults at Larvik and Landgangen (Fig. 2), which suggest a zone of relatively intense deformation in the Tvedalen area. The largest stoped pegmatites that were studied are found in quarries located in such areas (e.g., the Johs Nilsen quarry), which also coincide with topographical lineaments. Therefore, deformation of the host larvikite during cooling and ongoing evolution of the Oslo rift is the principal control mechanism of pegmatite melt-migration. However, the overall trends in the faults of the area are not reflected by the orientations of the pegmatites as they just provided a complex fracture system working as pathways for the pegmatite melts.

\section{Zonation of the Sagåsen pegmatite}

The three different segments that form the exposed part of pegmatite 1 in the Sagåsen quarry represent different textural and mineralogical transitions between distinct zones of a relatively large nepheline syenite pegmatite. The mineral assemblage in segment 1 through segment 3 shows an increasingly complex mineralogical evolution in respect to primary and secondary minerals. For instance, saccharoidal albite in segment 1 mainly hosts centimetre-large aegirine crystals and skeletal biotite, whereas in segment 3 albite hosts complex assemblages of wöhlerite, EGMs, astrophyllite and leucophanite. Hydrous alteration of primary feldspathoids is common throughout the pegmatite, but segment 1 is the most altered section where sodalite and most of the nepheline content are replaced by natrolite. Segment 1 expresses the starting point from which the main pegmatite body evolved by crystallisation of primary anhydrous mineral assemblages. The mixed rock hosting the pegmatite at the start of segment 1 and along the bottom contact of segment 2 is unique to the pegmatite, and although the rocks present are the same as found in stoped pegmatites, none of the rocks form angular blocks similar to the suspended larvikite. The intricate mixing of the various rocks is interpreted as being a result of a high volatile content resulting in the pegmatite formation. The mixing feature is localised in the immediate surrounding to the 


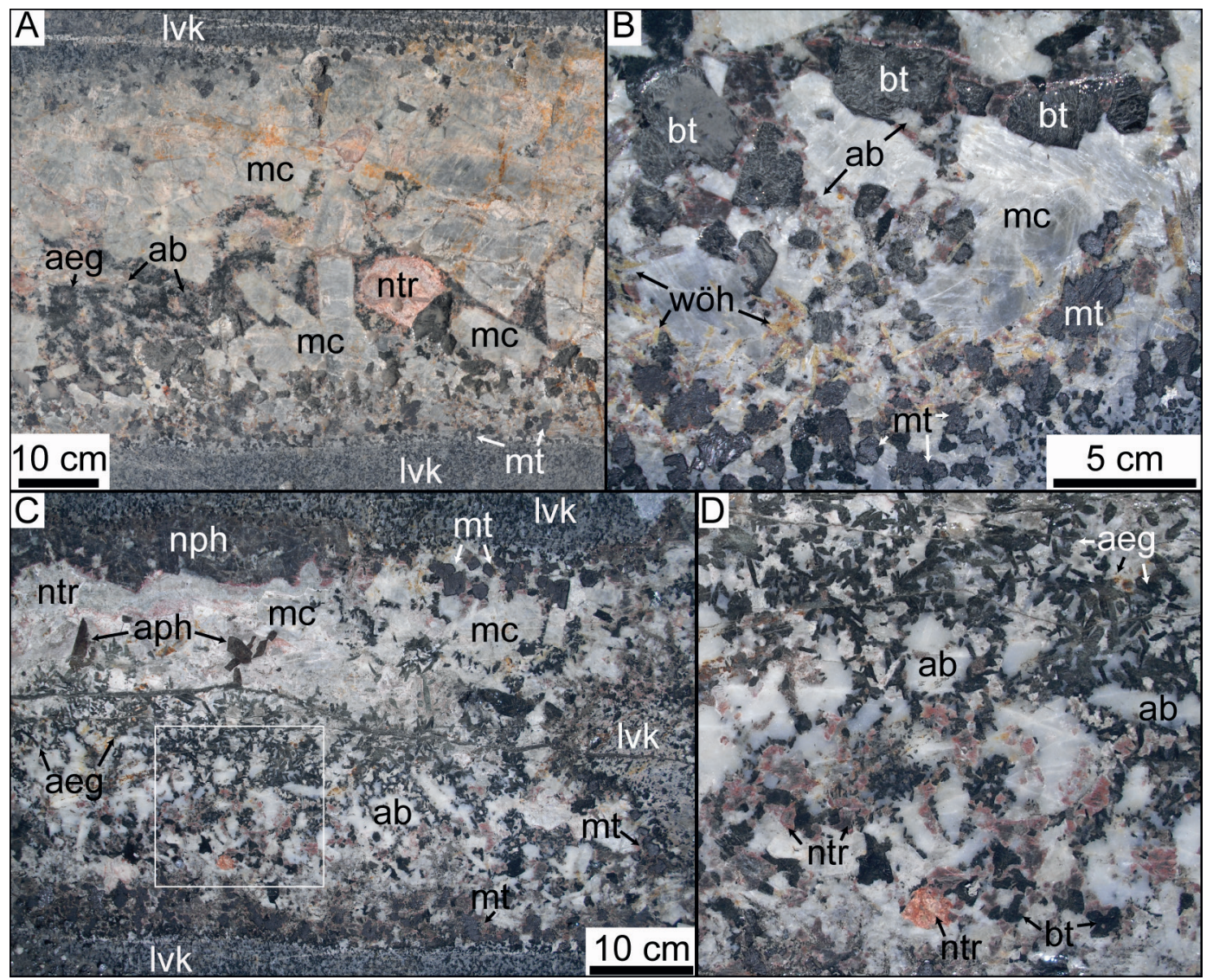

Figure 13. Field images showing characteristic features of pegmatite 2 in the Sagåsen quarry. (A) Section of the pegmatite containing large microcline crystals ( $\mathrm{mc}$ ), interstitial albite (ab) and aegirine (aeg), and natrolite replacement of feldspathoids (ntr). The cross-section is cut horizontally to the dip-angle of the dyke giving an apparent larger thickness. (B) View of the lower contact where wöhlerite (wöh), microcline $(\mathrm{mc})$, magnetite $(\mathrm{mt})$ and biotite $(\mathrm{bt})$ are the most abundant mineral assemblages. Magnetite and wöhlerite are concentrated along the bottom contact of the pegmatite. (C) Different section of the same pegmatite showing extensive saccharoidal albite (ab) relative to microcline. Feldspathoids within the pegmatite core are completely replaced by natrolite, while nepheline along the contact is partly altered along the crystal rim. Albite and aegirine compose the central core of the pegmatite. The right side of the image shows a subangular piece of larvikite (lvk) suspended within the pegmatite where magnetite crystallised along the larvikite contact. (D) Close-up view (white box, Fig. 13C) of albite, aegirine and natrolite replacement of nepheline. Abbreviations: ab - albite, aeg - aegirine, aph - astrophyllite, bt - biotite, lvk - larvikite, mc microcline, $m t$ - magnetite, $n p h$ - nepheline, ntr - natrolite, wöh - wöhlerite.

veins merging into segment 1 (Fig. 10) and the bottom contact of segment 2 . Within the three veins in segment 1 , cancrinite is the major interstitial phase whereas saccharoidal albite is the interstitial phase in segments 2 and 3 . In these segments, cancrinite is primarily a replacement feature in sodalite. The transition from cancrinite to saccharoidal albite as an interstitial phase is also interpreted as a significant mineralogical evolution where hydration of the pegmatite magma reaches a critical saturation level. Segments 2 and 3 therefore represent a section in which the pegmatite evolves towards increasingly diverse and complex mineral assemblages. The massive saccharoidal albite unit in segment 1 is mainly composed of anhydrous minerals with only minor skeletal biotite. In segments 2 and 3 the saccharoidal albite is confined to smaller isolated interstitial pockets, and is not such a strong feature as observed in segment 1.

\section{Timing of alteration}

The alteration observed in Sagasen pegmatites 1 and 2 is not clearly related to hydrothermal veins or exterior fluids, but more convincingly to in situ alteration of early formed feldspathoid or silicate minerals. This implies that the hydrous system is not driven by fluids circulating between larvikite and pegmatite, but must have emerged from crystallisation of the pegmatiteforming magma. Progressive crystallisation of anhydrous assemblages in the early magmatic phase would likely enrich the melt in a hydrous fluid, and thereby induce hydrous alteration of the early formed feldspathoids. Saccharoidal albite is a well-known feature of alkaline pegmatites and has been known for a long time (e.g., Vlasov et al., 1966). However, the origin of the albite zone has not received much attention, although Vlasov et al. (1966) called it hydrothermal in origin. Observations similar to the Sagåsen pegmatites are recorded from the Låven island where Brøgger (1890) described altered 
sodalite in one part of the pegmatite (e.g., similar to segment 1 of the Sagasen pegmatite), and where the mineral assemblages are clearly occurring in 'nests' (e.g., patches of låvenite, mosandrite, catapleiite). These differing mineral assemblages may represent contrasting conditions in the crystallising magma driven by exsolved late-magmatic fluids. A key feature for this mechanism is the crystallisation of saccharoidal albite and aegirine in the late-magmatic stages of pegmatite formation. Alteration along the crystal rim of primary minerals such as nepheline and wöhlerite is related to adjacent albite. In Sagåsen pegmatite 1, saccharoidal albite is a major part of the pegmatite internal structure (Fig. 9) defining the lower half of segment 1. Natrolite replacement of feldspathoids is common throughout the pegmatite profile, but most pronounced within segments 1 and 2. There are no observations of late hydrothermal veins intersecting primary magmatic textures (e.g., confined zeolite or calcite veins) or radiating outwards from the pegmatite into larvikite. Sørensen (1962) and Gerassimovsky (1964) described albite replacement of microcline and nepheline in complex agpaitic pegmatites of the Lovozero and Ilímaussaq intrusions, respectively. Although albite replacement was not observed for every complex pegmatite, albite clearly enclosed deformed primary aegirine suggestive of a later crystallisation. Contrary to this observation, evolved LPC pegmatites crystallised saccharoidal albite contemporaneously with aegirine in the late magmatic evolution of the pegmatites. Sørensen (1962) concludes that replacement bodies of the naujaite pegmatites in Ilímaussaq were driven by external fluids derived from cross-cutting veins consisting of identical mineral assemblages as the replacement bodies. Field observations and detailed studies of the exposed LPC pegmatites do not reveal any evidence of external fluids as a source of alteration. The majority of the primary minerals observed in Sagåsen pegmatite 1 are anhydrous, but still a significant part of the pegmatite shows alteration towards hydrous mineral assemblages such as zeolites. As argued above, there is no evidence for late external hydrothermal fluids interacting with the pegmatite. However, one observation provides an explanation, namely that there is a correlation between the amount of saccharoidal albite and the degree of zeolitisation observed in the various segments. The largest volume of saccharoidal albite occurs in segment 1 in which almost all primary feldspathoids have been replaced by zeolites. Conversely, segment 3 consists of abundant sodalite, but only has minor interstitial saccharoidal albite where alteration is observed in direct contact to or in the near proximity of albite. The mineral assemblage of saccharoidal albite domains is dominated by anhydrous minerals, while the secondary minerals nearby are hydrous. One mechanism for creating such a mineralogical change in solidified or close to solidified rocks is immiscibility of two melts. Immiscibility of silicate melts is not common, but some examples from alkaline complexes are known (Markl, 2001; Sørensen et al., 2003). Sørensen et al. (2003) described spheroidal structures up to $20 \mathrm{~cm}$ in diameter in lujavrite from the Ilímaussaq alkaline complex in which all the primary anhydrous feldspathoids have been replaced by analcime. The lujavrite spheroids are not interconnected and the alteration is limited to patches completely enclosed in unaltered lujavrite. These spheroids were interpreted as originating from immiscibility of a water-rich melt from the normal lujavrite melt during late-stage crystallisation. The water-rich melt reacted with the primary feldspathoids and formed the zeolites. Markl (2001) also showed how immiscibility within lujavrite in Ilímaussaq could create secondary zeolites after feldspathoids. We infer that the saccharoidal albite is formed as a result of immiscibility of a fluid phase during the late stages of pegmatite formation. The primary minerals of the pegmatite are almost exclusively anhydrous. As the pegmatite crystallises, the resulting melt becomes relatively enriched in water and at one stage expels a hydrous component, which then reacts with the already formed minerals. The main melt at this stage would be Na-rich and primarily crystallises albite and aegirine. The immiscibility also explains the correlation between zeolitisation and saccharoidal albite observed in the various segments of the Sagåsen pegmatite. Interestingly, the melt evolution resulting in the immiscibility of a hydrosaline melt also results in an increased alkalinity of the pegmatite. This is evident by EGMs, which are only present in the saccharoidal albite zone, and where the HFSE elements originated from the dissolution of primary wöhlerite.

\section{Classification of the pegmatites}

Previous classifications of the LPC pegmatites (Table 1) emphasised differences in morphology and mineral assemblages being related to geographical distribution. That is, easterly pegmatites such as RS 5 near the Stålaker quarry host a particular set of pegmatites relative to the Tvedalen and Langesundsfjord area. The quarries Malerød, Midtfjellet and Vardeåsen (Malerød; Fig. 1) situated in RS 7 contain syenite pegmatites which are similar to pegmatites in the Stavern area. Despite the geographical distance between these pegmatites they are similar in respect to both mineral assemblages and morphology. Primary zircon and pyrochlore are characteristic primary mineral assemblages in these pegmatites forming large and small crystals. These pegmatites form sharp contacts with larvikite and nepheline syenite have not been observed in this area. Saccharoidal albite does not form interstitially in these syenite pegmatites, and therefore it is a characteristic feature only associated with nepheline syenite pegmatites. Furthermore, the syenite pegmatites are similar in shape and size forming metre-thick sheets within the larvikite, and have not been observed forming stoped or kinked pegmatites. Brøgger (1890) noted a confined zone of 
Table 1. Summary of classification of LPC pegmatites.

\begin{tabular}{|c|c|c|c|c|c|}
\hline Pegmatite type & Brøgger & Andersen & Piilonen, Dahlgren & Morphology & RS \\
\hline Stavern $^{* 1,2,3,4}$ & $\begin{array}{l}\text { Zircon, pyrochlore, } \\
\text { zirconolite }\end{array}$ & $\begin{array}{l}\text { Zircon, pyrochlore, } \\
\text { zirconolite }\end{array}$ & Zircon, titanite & Dykes & $4,5,6$ \\
\hline Stålaker ${ }^{3,4}$ & & & Rutile, zirconolite & Pods, dykes & 5,8 \\
\hline Sandefjord $^{2}$ & & $\begin{array}{l}\text { Zircon, eudialyte, } \\
\text { catapleiite, } \\
\text { astrophyllite, } \\
\text { aenigmatite }\end{array}$ & & & 4 \\
\hline Tvedalen ${ }^{3,4}$ & & & $\begin{array}{l}\text { Wöhlerite, pyrochlore, } \\
\text { zircon, }\end{array}$ & Dyke & 6 \\
\hline Langesundsfjord ${ }^{1,2,3,4}$ & $\begin{array}{l}\text { I: Melinophan, } \\
\text { homilite } \\
\text { II: Catapleiite, } \\
\text { eudialyte }\end{array}$ & $\begin{array}{l}\text { Eudialyte, } \\
\text { astrophyllite, } \\
\text { cuspidine grp., } \\
\text { pyrochlore, }\end{array}$ & & $\begin{array}{l}\text { Dyke, irregular } \\
\text { veins, pods }\end{array}$ & 6 \\
\hline Bratthagen $^{3,4}$ & & $\begin{array}{l}\text { Lorenzenite, } \\
\text { parakeldyshite, } \\
\text { catapleiite, } \\
\text { astrophyllite, eudialyte }\end{array}$ & $\begin{array}{l}\text { Hilairite, loparite-(Ce), } \\
\text { lorenzenite, parakeldyshite, }\end{array}$ & $\begin{array}{l}\text { Irregular dyke to } \\
\text { lensoid }\end{array}$ & 10 \\
\hline External $^{3,4}$ & & & $\begin{array}{l}\text { Zircon, pyrochlore, } \\
\text { eudialyte, chevkinite, }\end{array}$ & Dyke, pods & \\
\hline
\end{tabular}

${ }^{1}$ Brøgger (1890), ${ }^{2}$ Andersen et al. $(2010,2013),{ }^{3}$ Piilonen et al. $(2012,2013),{ }^{4}$ Dahlgren (2010), ${ }^{*}$ former Fredriksvärn.

pegmatites carrying meliphanite in the Langesundfjord archipelago and attributed these pegmatites to a special meliphanite class. Meliphanite has since been found at other localities such as Vesterøya and Eidanger (Fig. 1), which are located in different ring sections and separated by several kilometres. Thus, there is no clear evidence for similarities between pegmatites specific to geographic area. However, some relations can be inferred based on features related to pegmatite formation: 1) Syenite pegmatites carrying primary zircon, pyrochlore, zirconolite and titanite. These pegmatites do not contain saccharoidal albite and are likely related to early formed pegmatites derived from less evolved larvikite (e.g., Neumann, 1980). 2) Intermediate nepheline syenite pegmatites characterised by albite-hosted late-magmatic EGMs and aegirine. Saccharoidal albite with aegirine is a characteristic feature for this group of pegmatites, and they may or may not occur with nepheline syenite. Wöhlerite is the most abundant $\mathrm{Na}-\mathrm{Zr}$ silicate occurring in these pegmatites. 3) Highly evolved nepheline syenite pegmatites with primary magmatic EGM and $\mathrm{Ti}-\mathrm{Na}$ silicates (e.g., mosandrite, låvenite). Wöhlerite is subordinate relative to hiortdahlite and rosenbuschite.

\section{Conclusions}

Alkaline pegmatites occurring in the LPC represent a wide range of mineral assemblages described as miaskitic or agpaitic. However, several pegmatites are not clearly representative of either of the two typical mineral assemblages, but constitute a unique group of intermediate pegmatites. The intermediate and agpaitic pegmatites represent highly evolved melts where a latemagmatic hydrosaline immiscible melt is formed by the crystallisation of anhydrous minerals. The extensive natrolite replacement of sodalite and nepheline is induced by an immiscible fluid phase. The intermediate group of pegmatites is characterised by the presence of late-magmatic saccharoidal albite with aegirine and EGMs.

Acknowledgements. Special thanks go to Torfinn Kjærnet for setting up UV-photography in the Sagåsen quarry and Alf Olav Larsen for logistics in the Langesundsfjord. Lundhs are thanked for access to their quarries and draining the Sagåsen quarry of water. An anonymous reviewer and Trond Slagstad helped improve the original manuscript. This study was funded by a Ph.D. stipend to the first author from the Natural History Museum of Oslo, University of Oslo, Norway. 


\section{References}

Andersen, T., Erambert, M., Larsen, A.O. \& Selbekk, R.S. 2010: Petrology of nepheline syenite pegmatites in the Oslo rift, Norway: Zirconium silicate mineral assemblages as indicators of alkalinity and volatile fugacity in mildly agpaitic magma. Journal of Petrology 11,2303-2325. https://doi.org/10.1093/petrology/egq058.

Andersen, T., Erambert, M., Larsen, A.O. \& Selbekk, R.S. 2013: Petrology of nepheline syenite pegmatites in the Oslo rift, Norway: $\mathrm{Zr}$ and Ti mineral assemblages in miaskitic and agpaitic pegmatites in the Larvik plutonic complex. Mineralogia 43, 3-40. https://doi.org/10.2478/mipo-2013-0007.

Baranwal, V. 2015: Compilation of various airborne geophysical data in the Oslofjord area. Norges geologiske undersøkelse Report 2013.030, $38 \mathrm{pp}$.

Brøgger, W.C. 1890: Die mineralien der syenitpegmatitgänge der Südnorwegischen augit- und nephelinesyenite. Zeitschrift für Krystallographie und Mineralogie 16, 1-663.

Ĉerný, P. 1991: Rare-element granitic pegmatites. Part I: Anatomy and internal evolution of pegmatite deposits. Geoscience Canada 18, 49-67.

Dahlgren, S. 2010: The Larvik plutonic complex: The larvikite and nepheline syenite plutons and their pegmatites. In Larsen, A.O. (ed.): The Langesundsfjord. History, Geology, Pegmatites, Minerals, Bode, Salzhemmendorf, pp. 26-37.

Dahlgren, S., Corfu, F. \& Heaman, L. 1998: Datering av plutoner og pegmatitter i Larvik pluton-kompleks, sydlige Oslo graben, ved hjelp av U-Pb isotoper i zirkon og baddeleyitt. Norsk Bergverksmuseum Skrift 14, 32-39.

Fersman, A.E. 1926: Minerals of the Kola Peninsula. American Mineralogist 11, 289-299.

Gerassimovsky, V.I. 1964: Specific features of mineralogy of agpaitic nepheline syenite pegmatites. Proceedings of section 6, report of the twenty-second session India, International Geological Congress, 225-241.

Groome, N.T. 2017: A description of the Bjønnes nepheline syenite intrusion, part of the Larvik plutonic complex, Norway. MSc thesis, Department of Geoscience, University of Oslo, $134 \mathrm{pp}$.

Heldal, T., Kjølle, I., Beard, L.P., Tegner, C. \& Lynum, R. 1999: Kartlegging av larvikitt mellom Sandefjord of Porsgrunn. Norges geologuiske undersøkelse Report 99.059, 68 pp.

Jahns, R.H. \& Burnham, W. 1969: Experimental studies of pegmatite genesis: I. A model for the derivation and crystallization of granitic pegmatites. Economic Geology 64, 843-864. https://doi.org/10.2113/gsecongeo.64.8.843.

Khomyakov, A.P. 1995: Mineralogy of hyperagpaitic alkaline rocks. Clarendon Press, Oxford, 223 pp.

Larsen, A.O. 1998: Identiteten til sorte glimmere i biotittserien fra syenittpegmatitter i Langesundsfjordområdet. Kongsberg Mineralsymposium 14, 5-8.

Larsen, A.O. 2010: The Langesundsfjord. History, geology, pegmatites, minerals. Bode, Salzhemmendorf, 239 pp.

Larsen, A.O., Åsheim, A. \& Gault, R.A. 2005: Minerals of the eudialyte group from the Sagåsen larvikite quarry, Porsgrunn, Norway. Norsk Bergverksmuseum Skrifter 30, 58-62.

Larsen, A.O., Stein, H.J., Hannah, J.L. \& Zimmerman, A. 2017: ReOs ages for molybdenites from the Saga I and Sagåsen larvikite quarries, Oslo Rift, South Norway. Norsk Mineralsymposium 2017, $77-84$.

Le Maitre, R.W., Streckeisen, A., Zanettin, B., Le Bas, M.J., Bonin, B., Bateman, P., Bellieni, G., Dudek, A., Efremova, S., Keller, J., Lameyre, J., Sabine, P.A., Schmid, R., Sørensen, H. \& Woolley, A.R. 2002: Igneous rocks: A classification and glossary of terms, recommendations of the international union of geological sciences subcommission on the systematics of igneous rocks. Cambridge University Press, New York, 236 pp.
https://doi.org/10.1017/CBO9780511535581.

London, D. 2008: Pegmatites. The Canadian Mineralogist Special Publication 10, 347 pp.

Lutro, O. \& Nordgulen, Ø. 2008: Oslofeltet, berggrunnskart, scale 1:250,000, Norges geologiske undersøkelse.

Markl, G. 2001: A new type of silicate liquid immiscibility in peralkaline nepheline syenites (lujavrites) of the Ilímaussaq complex, South Greenland. Contributions to Mineralogy and Petrology 141, 458-472. https://doi.org/10.1007/s004100100252.

Marks, M.A.W., Hettmann, K., Schilling, J., Frost, R.B. \& Markl, G. 2011: The mineralogical diversity of alkaline igneous rocks: Critical factors for the transition from miaskitic to agpaitic phase assemblages. Journal of Petrology 3, 439-455. https://doi.org/10.1093/petrology/egq086.

Neumann, E.R. 1980: Petrogenesis of the Oslo region larvikites and associated rocks. Journal of Petrology 21, 499-531.

https://doi.org/10.1093/petrology/21.3.499.

Neumann, E.R., Wilson, M., Heermans, M., Spencer, E.A., Obst, K., Timmerman, M.J. \& Kirstein, L. 2004: Carboniferous-Permian rifting and magmatism in southern Scandinavia, the North Sea and northern Germany: A review. Geological Society of London Special Publication 223, 11-40.

https://doi.org/10.1144/GSL.SP.2004.223.01.02.

Petersen, J.S. 1978: Structure of the larvikite-lardalite complex, Osloregion, Norway, and its evolution. Geologische Rundschau 67, 330342. https://doi.org/10.1007/BF01803271.

Piilonen, P.C., McDonald, A.M., Poirier, G., Rowe, R. \& Larsen, A.O. 2012: The mineralogy and crystal chemistry of alkaline pegmatites in the Larvik Plutonic Complex, Oslo rift valley, Norway. Part 1. Magmatic and secondary zircon: implications for petrogenesis from trace-element geochemistry. Mineralogical Magazine 76, 649672. https://doi.org/10.1180/minmag.2012.076.3.15.

Piilonen, P.C., McDonald, A.M., Poirier, G., Rowe, R. \& Larsen, A.O. 2013: Mafic minerals of the alkaline pegmatites in the Larvik Plutonic Complex, Oslo rift, Southern Norway. The Canadian Mineralogist 51, 735-770. https://doi.org/10.3749/canmin.51.5.735.

Rämö, O.T. \& Andersen, T. 2011: Magmatic evolution of the PermoCarboniferous Oslo rift: $\mathrm{U}-\mathrm{Pb}-$ and Lu-Hf-in-zircon evidence from the 299-289 Ma Larvik plutonic complex. Abstract V12B-02 presented at the 2011 Fall Meeting, American Geophysical Union, 5-9 December, San Francisco, CA.

Scheerer, T. 1843: Ueber den wöhlerit, eine neue mineralspecies; von Th. Scheerer in Christiania. Annalen der Physik und Chemie 59, 327-336. https://doi.org/10.1002/andp.18431350611.

Scheerer, T. 1852: Melinophan, eine neue mineralspecies. Journal für Praktische Chemie 55, 449-451. https://doi.org/10.1002/prac.18520550188.

Sunde, Ø., Friis, H. \& Andersen, T. 2018: Variation in major and trace elements of primary wöhlerite as an indicator of the origin of pegmatites in the Larvik plutonic complex, Norway. The Canadian Mineralogist 56, 1-14. https://doi.org/10.3749/canmin.1700050.

Sæbø, P.C. 1966: The first occurrences of the rare mineral barylite, $\mathrm{Be}_{2} \mathrm{BaSi}_{2} \mathrm{O}_{7}$, in Norway. Norsk Geologisk Tidsskrift 46, 335-348.

Sørensen, H. 1962: On the occurrence of steenstrupine in the Ilímaussaq massif, Southwest Greenland. Meddelelser om Grønland $167,1-253$.

Sørensen, H. 1967: On the history of exploration of the Ilímaussaq alkaline intrusion, South Greenland. Contributions to the mineralogy of Ilímaussaq 3, 1-32.

Sørensen, H. 1997: The agpaitic rocks - an overview. Mineralogical Magazine 61, 485-498.

https://doi.org/10.1180/minmag.1997.061.407.02.

Sørensen, H., Bailey, J.C., Kogarko, L.N., Rose-Hansen, J. \& KarupMøller, S. 2003: Spheroidal structures in arfvedsonite lujavrite, Ilímaussaq alkaline complex, South Greenland - an example of macro-scale liquid immiscibility. Lithos 70, 1-20. https://doi.org/10.1016/S0024-4937(03)00086-0. 
Ussing, N.V. 1912: Geology of the country around Julianehaab, Greenland. Meddelelser om Grønland 38, 1-426.

Vlasov, K.A., Kuz'Menko, M.Z. \& Es'Kova, E.M. 1966: The Lovozero alkali massif. Oliver and Boyd, Edinburgh and London, $627 \mathrm{pp}$.

Weibye, P.H. 1850: Neue mineralien aus Norwegen, beschrieben von P.H. Weibye; analysirt von N. J. Berlin, K. A. Sjögren und J. B. Borck. (Erster theil). Annalen den Physik und Chemie 19, 299-302.

Wöhler, F. 1826: Ueber den pyrochlor, eine neue mineralspesies. Annalen der Physik und Chemie 7, 417-428.

https://doi.org/10.1002/andp.18260830803. 